\title{
Quality Enhancement through Incorporating Student- centered Learning Methods in Higher Education Institutions (HEIs)
}

\author{
Guranda Khabeishvili, PhD Candidate \\ Assoc. Prof. Dr. Nino Tvaltchrelidze \\ International Black Sea University, Georgia
}

Doi:10.19044/esj.2021.v17n27p39

Submitted: 12 July 2021

Accepted: 13 August 2021

Published: 31 August 2021
Copyright 2021 Author(s)

Under Creative Commons BY-NC-ND

4.0 OPEN ACCESS

Cite As:

Khabeishvili G. \& Tvaltchrelidze N. (2021). Quality Enhancement through Incorporating Student-centered Learning Methods in Higher Education Institutions (HEIs). European Scientific Journal, ESJ, 17 (27), 39. https://doi.org/10.19044/esj.2021.v17n27p39

\section{Abstract}

One of the main tasks of higher education institutions is to attract their customers with its quality education. To improve education practices and to meet the challenges of an ever-changing environment, it is vital to introduce a paradigm shift in education. Hence, what we teach to our students is not enough, the way we teach them is what matters the most. There are several factors, which can serve as indicators of quality education. The demands, needs, expectations of the learners have changed. Accordingly, the primary goal of education is to provide the quality that ensures contemporary students not only with subject knowledge but also with the key skills needed for the $21^{\text {st }}$ century world. Although the concept of student-centeredness is not new, challenges still exist concerning incorporating all characteristics and elements of the student-centered learning approach in Higher Education Institutions in Georgia. According to the previous studies, it is noticeable that the lack of resources and staff training are some of the hindering factors to create and maintain student-centeredness in HEIs (Tvalchrelidze \& Alkesidze, 2019). The paper sheds light on the significance of making the classroom environment student-centered, as it can boost and maintain the quality of education for all students (Harris, Spina, Ehrich \& Smeed, 2013; Vavrus, Thomas, Bartlett, 2011). The primary objective of this paper is to identify teachers' perceptions of student-centered learning, along with the current 
instructional practices and challenges in the case of Higher Education Institutions in Georgia. Hence, it examines the level of integration of studentcentered strategies in the classrooms. For this reason, the quantitative paradigm was applied, as the methodology for the research. The research was carried out among lecturers from three different universities. The results depict that there is still a gap between the practical application of the student-centered learning methods and the perception of the concept, which can have an impact on ensuring quality education. Based on the gained data, it could be seen that less than $40 \%$ of lecturers from three different universities fully integrate student-centered learning methods. Furthermore, the research reveals some barriers that hinder the process of promoting the student-centered learning environment. Consequently, based on the findings the conclusions and recommendations were made. To deal with the hindering factors that were identified through this research, it is vital to modify and enhance institutionallevel approaches.

Keywords: Quality, Student-centered learning, Higher education, learning process, skills

\section{Introduction}

The primary objective of all developed and developing countries is to strive to make education a priority to ensure a strong economy and advanced society. Higher education institutions (hence HEIs) are trying to provide the best, competitive educational system so that they will be able to release highqualified employees for the market. The main concern is still regarding the concept of quality education since it could be interpreted in various ways by different institutions. The world changes constantly and it brings changes in our life as well. To adapt to the new, developing world we have to change the way we do things. Charles, Bernie, and Maya (2015) indicate that the system of education does not sufficiently prepare learners, in order to be successful in the future. It could be explained with the facts that education cannot catch up with all those changes quickly, which happen because of daily transformations in the world. Due to all those changes, this issue is topical and nowadays the universities are facing challenges in terms of it. There are a number of factors, which can serve as indicators of quality education. The demands, needs, expectations of the learners have changed. Hence, the primary goal of education is to provide the quality that ensures contemporary students not only with subject knowledge but also with the key skills needed for the $21^{\text {st }}$ century world. So, the quality of education depends on lots of factors including human and material resources. However, it is very difficult to measure the quality of education because of different views and ideas about quality education itself. Still, there are some generally acknowledged definitions about what quality is 
and what factors indicate and improve quality education. Ensuring quality education is tightly related to the paradigm shift in both learning and teaching processes (Gaebel and Zhang, 2018). Moving from a teacher-centered form of instruction to a student-centered one has brought some modifications in the way the educators see the teaching and learning practices. Consequently, implementing student-centered learning in the classrooms has become significant (Zohrabi, Torabi, Baybourdiani,2012 cited in Emaliana,2017). Even though this type of instructional mode is not a new concept, it remains a challenge to fully integrate the practices of the student-centered approaches in higher education institutions. It is considered to be essential for ensuring quality education. According to research, the insufficient number of teacher training and the resources needed for creating a student-centered environment are considered to be some challenging factors for its proper application in the case of Georgia (Tvalchrelidze, Alkesidze, 2019). Moreover, the report published by the European students' Union (ESU) (2015) on Bologna with Student Eyes, clearly indicates that Europe's HEIs do not do the things according to the plans, concerning the application of student-centered learning, which is considered as the key to developing a broad range of skills. The impact of this way of instruction was put forward even more after introducing the Bologna system in 1999. The learning outcomes were revised by Standards and Guidelines for Quality Assurance and the Bologna Process, which gave a start to promote student-oriented learning (ESG,2015; Attard, Di Ioio, Geven, \& Santa, 2010). According to the European University Association (EUA) (2018), ensuring students with a high-quality learning experience, taking their needs into account, and striving for progress should be integrated as the main part of the universities' mission. The main priority that was highlighted in the Standards and Guidelines was concerning encouraging students to take active roles in creating the learning process and designing the study programs in a way to meet these standards (ESG, 2015). Crozier, Loukkola, Michalk (2016) point out that the introduction of this standard made this issue more prevalent among the quality assurance community. Therefore, the approach referred to as a student-centered one can enhance and stimulate such a learning environment, where the students are the key participants and are very active in the construction of their learning. Furthermore, many benefits are associated with the application of studentcentered learning, including improving both learning and teaching practices through enhancing transversal skills. In light of this, this form of instruction is believed to prepare students for both the current and future labor market (Warming and Frydensberg, 2017).

Considering the recent evidence reported by Gaebel and Zhang (2018) there is still the need of making necessary policy changes, and HEIs are expected to concentrate more on making the learning experience better. 
Despite many efforts to redesign the learning environment, it is still found to be challenging to address student-centered learning. Gover and Loukkola (2018) claim that one of the reasons is the lack of a common perception of the concept. Integration of student-centered learning is believed to be a contextsensitive notion, like quality assurance since it can be implemented differently in various settings. It is noteworthy to mention that common characteristics of student-centered learning are connected to students' autonomy, as they are actively engaged in their learning. They are encouraged to gather information, synthesize and integrate it with the skills of critical thinking, problem-solving, inquiry, and communication (Shofer, 2020). In light of this, the concept is generally understood as designing the learning process in a way to acknowledge their needs, interests, expectations, learning styles, and personal challenges (Suresh \& Rajest,2019). A similar view is shared by Kaput (2018) that this instructional practice fully concentrates on the learners and the process is greatly personalized. In this sense, according to Gover, Loukkola, \& Peterbauer (2019), this concept implies engaging students in shaping their learning process, by taking into account their backgrounds and experiences. In addition, engaging students in a decision-making process is one of the tenants of such an instructional model. The student's voice should be the central part of their learning process, which involves various aspects, such as encouraging them to decide what to study, how and when to do it. Consequently, incorporating student-centered learning does not imply only one method. It is about integrating a set of pedagogical techniques and approaches to foster a student-oriented environment. Correspondingly, the following research questions have been formulated: What is the perception of student-centered learning among the teachers in Georgia? What types of instructional practices are applied to foster student-centered learning in the case of Higher Education Institutions in Georgia? Therefore, after the introduction, the paper follows different sections. First, it provides a brief overview of the quality assurance concept and student-centeredness. Methodology, methods, and analysis of gained data are discussed after giving a literature review regarding the concepts of this research.

\section{Quality assurance in fostering student-centered learning}

In order to enhance quality through incorporating student-centered learning methods, it is crucial to consider the role of quality assurance in promoting student-centered learning. According to the recent study (Kivistö \& Pekkola, 2017), three quality assurance dimensions are distinguished, which could be considered as a helpful framework for mapping several aspects of institutional quality assurance. The following chart illustrates these dimensions with their processes and activities that can foster student-centered learning. 
Chart 1. Quality assurance dimensions

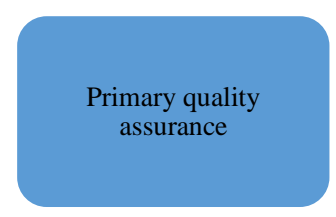

For ensuring studentcentered approaches offering pedagogical tranings How to evaluate studentcenteredness

How to implement the methods in the classroom
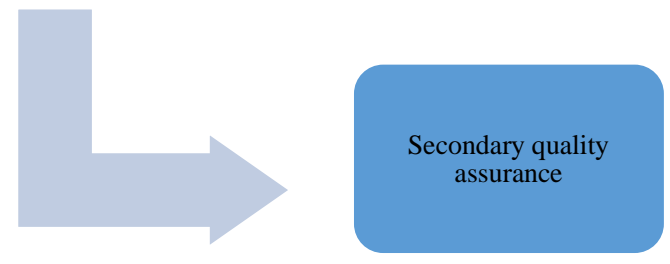

Embedding a student-centred mindset into existing quality. Programme design Teaching guidelines Teaching evaluations Measures for collecting student feedback.
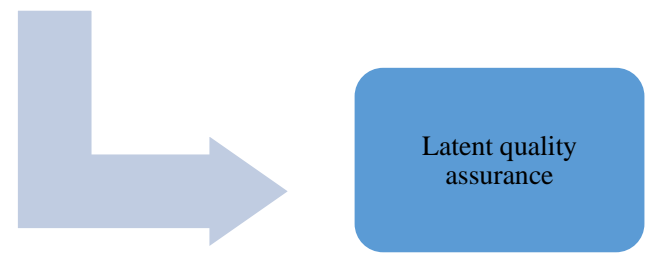
Take teaching competences into account in a way that implicitly fosters student- centred approaches Strategic plans Mission statements Teaching awards

Regarding this, one of the main aspects mentioned in the standards for quality assurance refers to boosting student-centered learning and teaching, since it stimulates learners' self-reflection, motivation, and involvement in the learning path. This is what internal quality assurance is concerned with. These are the set of guidelines compiled by ESG (2015), which reflects how the programs should be designed, delivered, and assessed. Standard 1.3 "The implementation of student-centered learning and teaching

- respects and attends to the diversity of students and their needs, enabling flexible learning paths;

- considers and uses different modes of delivery, where appropriate;

- flexibly uses a variety of pedagogical methods;

- regularly evaluates and adjusts the modes of delivery and pedagogical methods;

- encourages a sense of autonomy in the learner while ensuring adequate guidance and support from the

- teacher;

- promotes mutual respect within the learner-teacher relationship;

- has appropriate procedures for dealing with students' complaints" (ESG, 2015, p. 12). 
Competition among universities is increasing in every country. Due to this fact, one of the main tasks of higher education institutions is to attract their customers with quality education. When we are talking about quality, the key players are the customers of the product. Quality of education is measured, assessed by clients: students, parents, employers, and government. Sallis (2002) argues that the judgments regarding the quality are made by the customer. Since the students are viewed as customers; they are directly affected by the quality. Therefore, creating a student-oriented environment allows them to make decisions, choices, construct their learning through teachers' guidance, meet their needs and interests.

Additionally, UNICEF (2000) discusses what quality education generally includes:

- The support from the community and the family to ensure the learners are healthy and ready for a learning journey.

- Safe and protective environment, where the learners are given sufficient facilities and resources.

- The content that is given in the curriculums should support the learners to acquire some basic and life skills. Moreover, the learners need to obtain knowledge in different areas, such as peace, health, gender, and so on.

- The application of children-centered/learner-centered methods and the assessment techniques, which support the learning process.

- The learning outcomes should not only be oriented on gaining the knowledge, but also obtaining the skills and attitudes, which can reflect the national goals of education.

Accordingly, both teaching and learning approaches have shifted from the traditional teacher-centered method into the modern, student-centered method, in order to meet contemporary learners' interests, needs and expectations. The concept of good quality education is seen as studentoriented, which implies allowing them the opportunity to gain knowledge, obtain skills and abilities to fully function in society. This approach is highly valued in modern education, as it plays a crucial role in enhancing quality. Hence, the teaching and learning practices need to be modified in a way to benefit all types of learners.

\section{Method}

The goal of the research is to get a clear picture in terms of perceptions of the lecturers regarding student-centered learning in Higher Education Institutions in Georgia. Moreover, it examines the level of integration of student-centered strategies and the challenges of practicing them. 
So, the quantitative paradigm was chosen as the methodology for the research. The reason for this is that it enables the researcher to gather a large amount of data from respondents in relatively little time. Eyisi (2016) argues that the quantitative research approach is the research that emphasizes numbers and figures while collecting and analyzing the data.

The lecturers were given an online survey consisting of eight questions. While obtaining primary data, the Survey Monkey platform was used. Forty respondents from three different universities (two private and one state) had been randomly chosen as the sample, who answered eight questions, a mixture of multiple-choice, Likert-style, open-ended, and ranking. After obtaining the results, for the multiple-choice questions, the diagrams were created and the data analysis is given in the percentages. For each Likert-scale question and item, descriptive statistics were also performed using SPSS to show how statistically significant and reliable the results are.

The participants were the teachers with different titles, who deliver general English language courses or English Language Teaching (ELT) related courses to students majoring in various fields, such as Psychology, Philology, Architecture, International relations, Information technology, Business administration, and Tourism.

All participants have been explained at the beginning of a survey that their participation was voluntary and they could withdraw themselves at any stage of the research with no further consequences. Their responses were anonymous and their participation was closed to publicity.

Hence, it describes the research carried out at ' $\mathrm{X}$ ' state and two private universities, through a survey.

\section{Results}

\section{Q1: Please indicate your title}

Fig. 1. The title of teachers at university

Answered: 40 Skipped: 0

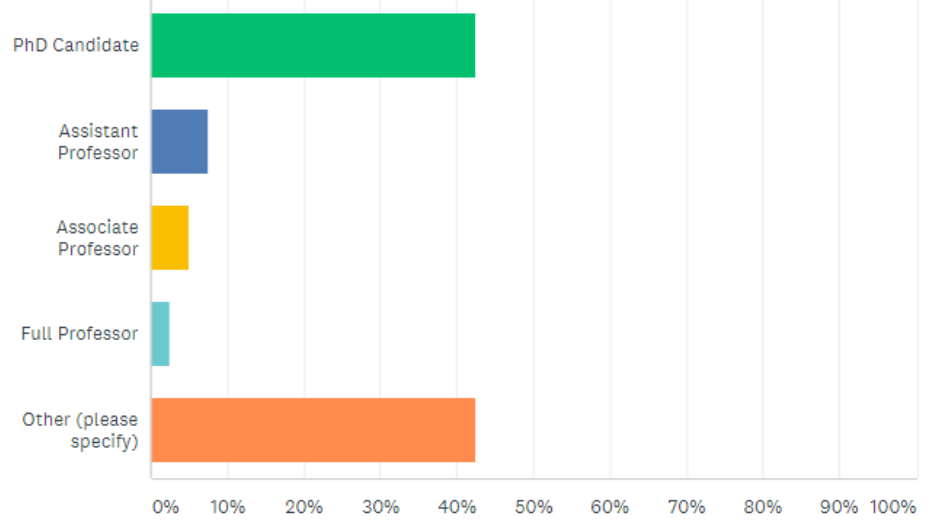


The first two questions of the survey were asked to participants to get background information about their teaching experience. The majority of respondents are invited lecturers (40\%), who teach the general English language and Ph.D. candidates in the field of education. $10 \%$ of the participants hold an assistant professor title at universities.

\section{Q2: How many years have you been teaching?}

Fig. 2. Teaching experience

Answered: 40 skipped: 0

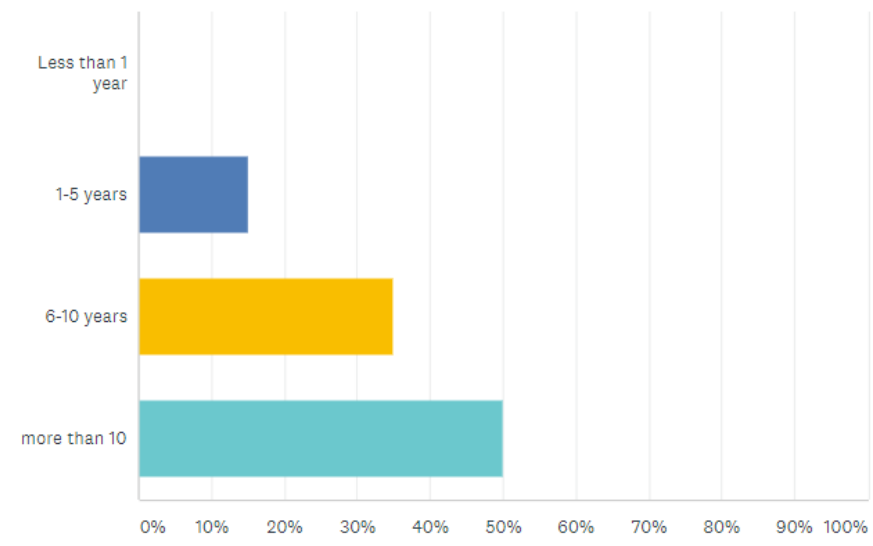

According to the figure, it can be seen that most participants have been working as teachers for more than ten years. Hence, the participants of this survey have a great experience of working with different types of students and have been involved in teaching practices for a long time.

\section{Q3: How do you understand/define Student-centered Learning (SCL)?} What are the important characteristics of SCL in your opinion?

The teachers' awareness of the concept

Considering the answers of the participants regarding the perception of student-centered learning, it could be said that the majority of them are aware of the concept. Even though they define this type of instruction mode with different words, there is still a common understanding of the concept. All of them share similar opinions and believe that the role of the teacher is a facilitator and the students are active participants in the construction of their learning. Some answers to the open-ended question are given below:

- Tailoring the curriculum based on students' needs, Facilitating students' learning on their own.

- A Teacher is just the director that organizes the process of teaching, everything is done by students 
- The teacher plays the role of facilitator and assists them to give direction to ensure learners' autonomy and independence.

- Attention to students' background knowledge and experience of the subject and adapting the course to fit their needs and abilities. Prioritizing student learning over content coverage. Using teaching methods that encourage student engagement.

- In student-centered learning processes, teachers served as companions instead of instructors. It is their vital task to lead the students towards interpreting the subject matter and thereby 'experiencing' its contents.

- Student-centered learning takes into account the context, level, and interest of the students. It does not force curriculum on students but rather adapts materials to challenge students at their level to progress in their understanding. It also seeks to incorporate relevant aspects of their experience, environment, and needs into the learning process.

- In student-centered learning, great attention is paid to students' learning styles, interests and abilities. Besides, student speaking/ activity time exceeds teacher speaking time. Also, students have the choice of topics (or sub-topics inside the compulsory topic studies), activities, and the assessment forms. And finally, part of the assessment is done as student self-assessment.

Q4: What are the teaching-learning methods included in the curriculum and the courses in your institution?

Fig. 3. The degree of student-centeredness

Answered: 40 Skipped: 0

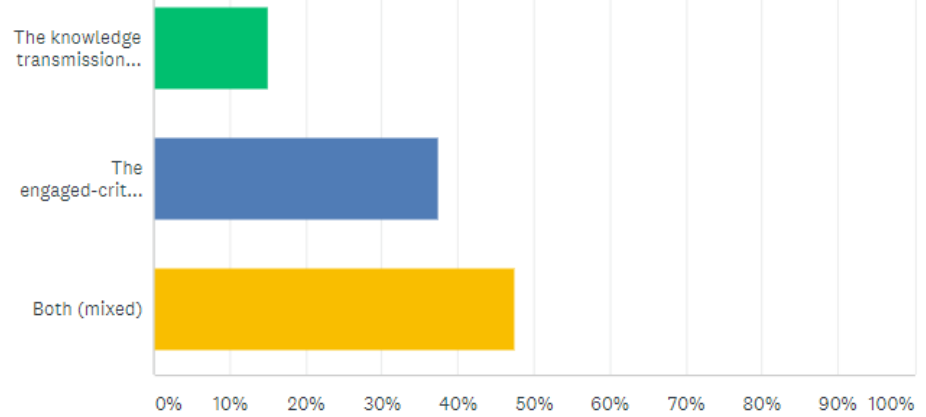

The question aimed to determine which form of instruction is more dominant in Higher Education Institutions in Georgia. The participants had three different answer choices: 1. The knowledge transmission model 
(teacher-centered) 2. The engaged-critical model (learner-centered) 3. Both (a mixed). According to this figure, almost half of the participants indicate that a mixed model is applied in HEIs. Less than $20 \%$ of respondents think that the teacher-centered learning form of instruction is still being practiced at universities. Though less than $20 \%$ of the participants think so, it still poses a big problem for Georgian students and HEIs.

Q5: Please rate the effectiveness of teacher-centered, learners-centered, and mixed (teacher-centered and learner-centered) methods

Fig. 4. The teachers' perception regarding its effectiveness:

\begin{tabular}{|c|r|r|r|}
\hline & $\begin{array}{c}\text { VAR0001 } \\
\text { Teacher- } \\
\text { centered }\end{array}$ & $\begin{array}{c}\text { VAR00002 } \\
\text { Learner- } \\
\text { centered }\end{array}$ & $\begin{array}{c}\text { VAR00003 } \\
\text { Mixed }\end{array}$ \\
\hline $\mathrm{N}$ & 40 & 40 & 40 \\
Missing & 0 & 0 & 0 \\
Mean & 2.1250 & 4.3250 & 3.3500 \\
Median & 2.0000 & 4.0000 & 3.0000 \\
Mode & 2.00 & 4.00 & 3.00 \\
Std. Deviation & .82236 & .69384 & .76962 \\
Skewness & .050 & -1.025 & .357 \\
& & & \\
Kurtosis & -.891 & 1.805 & -.008 \\
\hline
\end{tabular}

According to the descriptive statistics, it can be seen that Mean, Median, Mode are close. So, there is a normal distribution and the results represent the real situation. Std. Deviation in all cases is above 0.5, which means that the group is heterogeneous and the results are reasonably reliable. As for the Skewness and Kurtosis, they are between -3 and 3 in all items, hence the answers are extremely reliable. The table below shows the results of the same question in the percentages. 


\begin{tabular}{|c|c|c|c|c|c|c|c|}
\hline & $\checkmark$ & $\begin{array}{l}\text { NOT AT ALL } \\
\text { EFFECTIVE }\end{array}$ & $\begin{array}{l}\text { SOMEWHAT } \\
\text { EFFECTIVE }\end{array}$ & $\begin{array}{l}\text { MODERATELY } \\
\text { EFFECTIVE }\end{array}$ & $\begin{array}{l}\text { VERY } \\
\text { EFFECTIVE }\end{array}$ & $\begin{array}{l}\text { EXTREMELY } \\
\text { EFFECTIVE }\end{array}$ & TOTAL \\
\hline$\nabla$ & $\begin{array}{l}\text { Teacher- } \\
\text { centered }\end{array}$ & $\begin{array}{r}25.00 \% \\
10\end{array}$ & $\begin{array}{r}40.00 \% \\
16\end{array}$ & $\begin{array}{r}32.50 \% \\
13\end{array}$ & $\begin{array}{r}2.50 \% \\
1\end{array}$ & $\begin{array}{r}0.00 \% \\
0\end{array}$ & 40 \\
\hline$\nabla$ & $\begin{array}{l}\text { Learners- } \\
\text { centered }\end{array}$ & $\begin{array}{r}0.00 \% \\
0\end{array}$ & $\begin{array}{r}2.50 \% \\
1\end{array}$ & $\begin{array}{r}5.00 \% \\
2\end{array}$ & $\begin{array}{r}50.00 \% \\
20\end{array}$ & $\begin{array}{r}42.50 \% \\
17\end{array}$ & 40 \\
\hline & Mixed & $\begin{array}{r}0.00 \% \\
0\end{array}$ & $\begin{array}{r}10.00 \% \\
4\end{array}$ & $\begin{array}{r}40.00 \% \\
16\end{array}$ & $\begin{array}{r}30.00 \% \\
12\end{array}$ & $\begin{array}{r}20.00 \% \\
8\end{array}$ & 40 \\
\hline
\end{tabular}

Based on this figure, the teachers' responses regarding the effectiveness of teacher-centered, learners-centered or mixed methods vary. $40 \%$ of them still consider teacher-centered learning mode as somewhat effective and $32.50 \%$ - moderately effective. Only very few of them believe that it is not effective at all. As for learner-centered learning methods, the answers are more positive. $42.50 \%$ assume that it is extremely effective, while $50 \%$ of them think that implementation of these methods is very effective. In the case of using the mixed types of instruction, only $20 \%$ of them consider it to be extremely effective.

\section{Q6: What are your past experiences of using SCL strategies in the classroom?}

Fig. 5. The level of integration of SCL strategies

Answered: 40 Skipped: 0

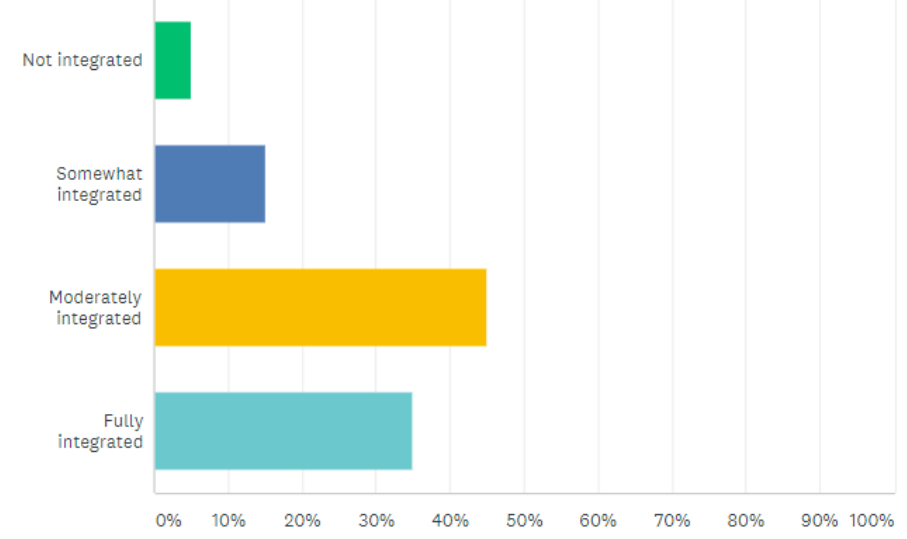

Less than half of the participants moderately apply student-centered learning strategies in the classroom, while $35 \%$ of them fully integrate the methods in their teaching practices. Thus, it is evident that unfortunately the vast majority of the respondents $(65 \%)$ either do not use SCL strategies effectively or they do not apply them at all (10\%). 


\section{Q7: What are the challenges of practicing SCL in your current environment? (You can tick more than one answer)}

Fig. 6. The challenges of practicing SCL strategies

\begin{tabular}{|l|l|}
\hline ANSWER CHOICES- & RESPONSES- \\
\hline -I can't cover the content in my syllabus using & $35.00 \%$ \\
SCL approaches & 14 \\
\hline -I can't use SCL approaches when teaching & $30.00 \%$ \\
large classes & 12 \\
\hline -I lack experience using SCL & $15.00 \%$ \\
& 6 \\
\hline -Students have negative attitudes toward SCL & $22.50 \%$ \\
& 9 \\
\hline -It is difficult to evaluate students using the & $27.50 \%$ \\
SCL approach & 11 \\
\hline -There is a lack of resources for SCL at my & $32.50 \%$ \\
university & 13 \\
\hline -There are no guidelines for the SCL approach & $30.00 \%$ \\
at my university & 12 \\
\hline -Responses & $25.00 \%$ \\
Other (please specify) & 10 \\
\hline Total Respondents: 40 & \\
\hline
\end{tabular}

According to their answers, some hindering factors to implement and integrate student-centered learning methods are the lack of resources for SCL at their universities (32.50\%). In addition, as stated above there are no guidelines for the SCL approach at their universities (30.00\%). The students' negative attitudes toward SCL $(22.50 \%)$ are also mentioned as one of the reasons for not integrating this form of instruction by some of the respondents. The majority of them also consider that they cannot cover the content in their syllabus using SCL approaches (35.00\%). Moreover, some even state other barriers to SCL.

Some other barriers

- Students lack a thorough understanding of SCL as well.

- Not all students are involved especially passive ones

- I don't take much time seeking out new SCL methods.

- Students are not used to it

- Due to the current epidemic situation, the distance teaching method can be one of the challenges of practicing SCL in my current environment. 


\section{Q8: Thinking of a course you have taught recently, to what extent did you integrate these practices in your teaching?}

Fig. 7. The level of student-centered practices integration

Statistics

\begin{tabular}{|c|c|c|c|c|c|c|c|c|c|c|c|c|}
\hline & $\begin{array}{c}\text { VAR0000 } \\
1\end{array}$ & $\begin{array}{c}\text { VAR0000 } \\
2\end{array}$ & $\begin{array}{c}\text { VAR0000 } \\
3\end{array}$ & $\begin{array}{c}\text { VAR0000 } \\
4\end{array}$ & $\begin{array}{c}\text { VAR0000 } \\
5\end{array}$ & $\begin{array}{c}\text { VAR0000 } \\
6\end{array}$ & $\begin{array}{c}\text { VAR0000 } \\
7\end{array}$ & $\begin{array}{c}\text { VAR0000 } \\
8\end{array}$ & $\begin{array}{c}\text { VAR0000 } \\
9\end{array}$ & $\begin{array}{c}\text { VAR0001 } \\
0\end{array}$ & $\begin{array}{c}\text { VAR0001 } \\
1\end{array}$ & $\begin{array}{c}\text { VAR0001 } \\
2\end{array}$ \\
\hline $\mathrm{N}$ Valid & 40 & 40 & 40 & 40 & 40 & 40 & 40 & 40 & 40 & 40 & 40 & 40 \\
\hline Missing & 0 & 0 & 0 & 0 & 0 & 0 & 0 & 0 & 0 & 0 & C & 0 \\
\hline Mean & 4.1250 & 3.9500 & 4.2000 & 3.7500 & 3.8750 & 3.8500 & 3.6750 & 4.0250 & 3.1250 & 3.0000 & 2.9500 & 3.8000 \\
\hline Median & 4.0000 & 4.0000 & 4.5000 & 4.0000 & 4.0000 & 4.0000 & 4.0000 & 4.0000 & 3.0000 & 3.0000 & 3.0000 & 4.0000 \\
\hline Mode & 5.00 & 4.00 & 5.00 & 4.00 & 4.00 & 4.00 & 4.00 & 5.00 & 3.00 & 3.00 & 3.00 & 4.00 \\
\hline $\begin{array}{c}\text { Std. } \\
\text { Deviation }\end{array}$ & 1.04237 & 1.08486 & 1.04268 & 1.03155 & 1.04237 & 1.05125 & .91672 & 1.09749 & 1.32409 & 1.33973 & 1.21845 & 1.09075 \\
\hline Skewness & -.976 & -1.165 & -1.423 & -.498 & -.740 & -.801 & -.549 & -1.032 & .178 & .000 & .100 & -.704 \\
\hline Kurtosis & -.218 & 1.123 & 1.551 & -.181 & .086 & .121 & -.391 & .298 & -1.076 & -1.036 & -.824 & -.251 \\
\hline
\end{tabular}

This table reveals the results gained from the analysis of the descriptive statistics. Std. Deviation in all cases is above 0.5 , which shows that the level of the participants' knowledge differs and the results are reliable. Skewness and Kurtosis, which are between -3 and 3 also show that the difference is not dramatic. Considering Mean, Median, Mode, it can be seen that there is a normal distribution. The given table below illustrates the results of the same question in the percentages. 


\begin{tabular}{|c|c|c|c|c|c|c|c|}
\hline & $\checkmark$ & NEVER $>$ & RARELY & SOMETIMES & OFTEN & REGULARLY & TOTAL \\
\hline$\checkmark$ & $\begin{array}{l}\text { I structure } \\
\text { class so that } \\
\text { students } \\
\text { regularly talk } \\
\text { with one } \\
\text { another about } \\
\text { course } \\
\text { concepts. I } \\
\text { stimulate } \\
\text { cooperation } \\
\text { among } \\
\text { students. }\end{array}$ & $\begin{array}{r}0.00 \% \\
0\end{array}$ & $\begin{array}{r}12.50 \% \\
5\end{array}$ & $\begin{array}{r}10.00 \% \\
4\end{array}$ & $\begin{array}{r}30.00 \% \\
12\end{array}$ & $\begin{array}{r}47.50 \% \\
19\end{array}$ & 40 \\
\hline$\checkmark$ & $\begin{array}{l}\text { I help } \\
\text { students to } \\
\text { refine their } \\
\text { understanding } \\
\text { by using } \\
\text { critical } \\
\text { thinking skills. }\end{array}$ & $\begin{array}{r}5.00 \% \\
2\end{array}$ & $\begin{array}{r}5.00 \% \\
2\end{array}$ & $\begin{array}{r}15.00 \% \\
6\end{array}$ & $\begin{array}{r}40.00 \% \\
16\end{array}$ & $\begin{array}{r}35.00 \% \\
14\end{array}$ & 40 \\
\hline$\checkmark$ & $\begin{array}{l}\text { I guide } \\
\text { students } \\
\text { through major } \\
\text { topics. I act as } \\
\text { a facilitator }\end{array}$ & $\begin{array}{r}2.50 \% \\
1\end{array}$ & $\begin{array}{r}7.50 \% \\
3\end{array}$ & $\begin{array}{r}7.50 \% \\
3\end{array}$ & $\begin{array}{r}32.50 \% \\
13\end{array}$ & $\begin{array}{r}50.00 \% \\
20\end{array}$ & 40 \\
\hline$\checkmark$ & $\begin{array}{l}\text { I provide } \\
\text { feedback on } \\
\text { student } \\
\text { assignments } \\
\text { without } \\
\text { assigning a } \\
\text { formal grade }\end{array}$ & $\begin{array}{r}2.50 \% \\
1\end{array}$ & $\begin{array}{r}7.50 \% \\
3\end{array}$ & $\begin{array}{r}30.00 \% \\
12\end{array}$ & $\begin{array}{r}32.50 \% \\
13\end{array}$ & $\begin{array}{r}27.50 \% \\
11\end{array}$ & 40 \\
\hline 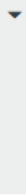 & $\begin{array}{l}\text { I design } \\
\text { activities that } \\
\text { connect } \\
\text { course } \\
\text { content to my } \\
\text { students' } \\
\text { lives and } \\
\text { future work }\end{array}$ & $\begin{array}{r}2.50 \% \\
1\end{array}$ & $\begin{array}{r}7.50 \% \\
3\end{array}$ & $\begin{array}{r}22.50 \% \\
9\end{array}$ & $\begin{array}{r}35.00 \% \\
14\end{array}$ & $\begin{array}{r}32.50 \% \\
13\end{array}$ & 40 \\
\hline$\vec{v}$ & $\begin{array}{l}\text { I structure } \\
\text { problems so } \\
\text { that students } \\
\text { consider } \\
\text { multiple } \\
\text { approaches to } \\
\text { finding a } \\
\text { solution. }\end{array}$ & $\begin{array}{r}2.50 \% \\
1\end{array}$ & $\begin{array}{r}10.00 \% \\
4\end{array}$ & $\begin{array}{r}17.50 \% \\
7\end{array}$ & $\begin{array}{r}40.00 \% \\
16\end{array}$ & $\begin{array}{r}30.00 \% \\
12\end{array}$ & 40 \\
\hline
\end{tabular}




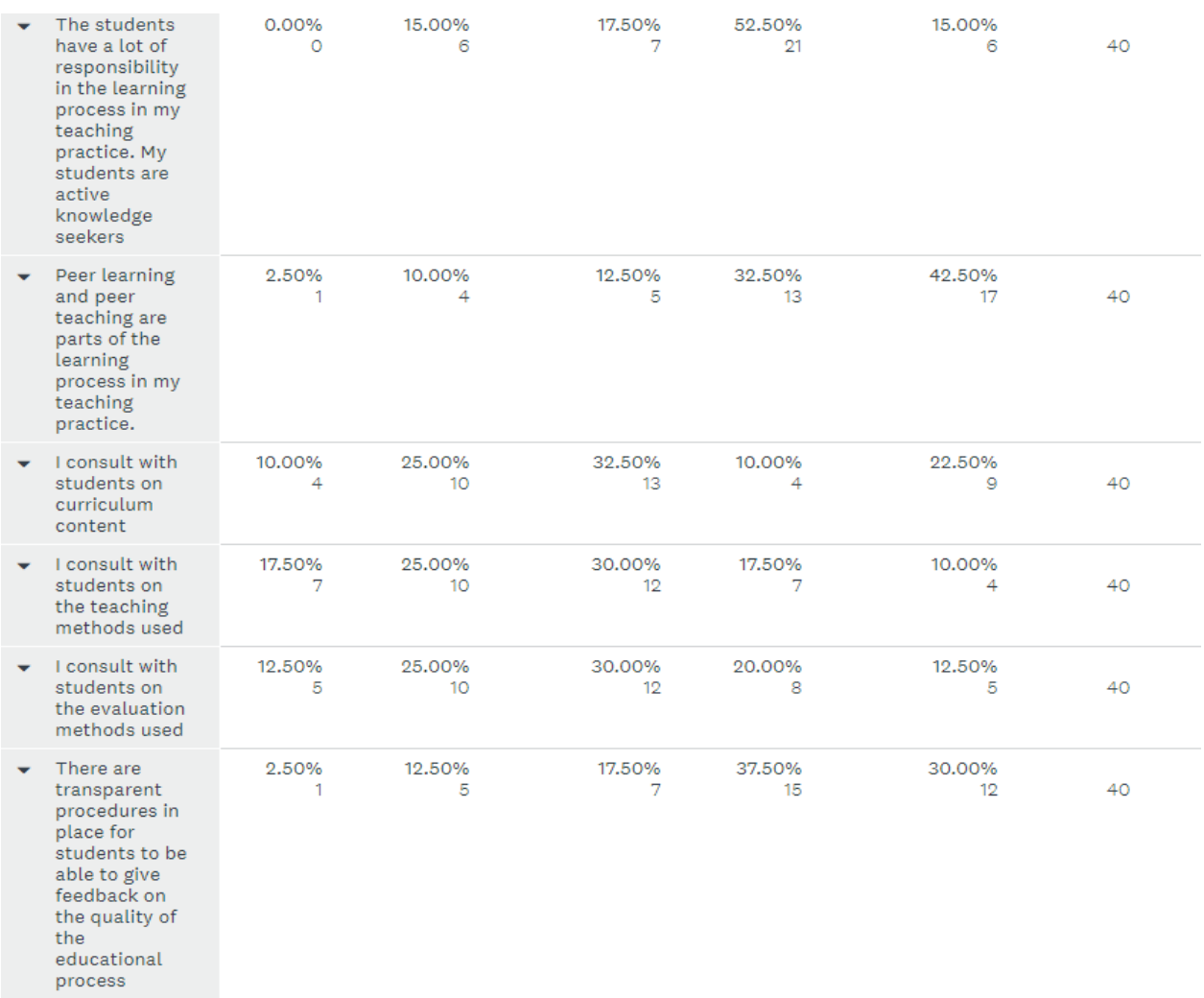

Reflecting on the practices, which teachers integrate into their teaching to ensure a student-centered learning environment, the responses are diverse. The most frequently applied strategies are giving them a chance to cooperate (regularly - 47.50\%) and being in a role of a facilitator (regularly 50\%). Moreover, according to the participants, they regularly use peer learning and learning teaching strategies $(42.50 \%)$. They also often encourage them to think critically $(40 \%)$.

The application of these practices enhances student-centeredness in the classroom, but it is not only enough. Only a few respondents often give feedback on learners' assignments without a formal grade (32.50\%). Merely $15 \%$ of the participants stated that their students are regularly active knowledge seekers and take ownership over their learning process. The minority of the respondents consult with students on the teaching methods $(10 \%)$ and the evaluation methods $(12.50 \%)$ used on a regular basis.

\section{Discussion}

Concerning this research, it could be seen that there is no problem regarding the understanding of the concept of student-centered learning among lecturers in Georgia. Even though they are aware of the concept, only a minority $35 \%$ fully integrates student-centered learning methods in their 
teaching practices. Despite many efforts to redesign the classroom environment, many students are still asked to absorb the mass amount of information. Many of them sit in rows and raise their hands to let their voices be heard. The teachers implement some strategies of student-centered learning, but not all methods are fully incorporated in the teaching and learning processes. Some barriers to applying it fully appear to be the students' attitude towards this type of instruction, the lack of guidance and support from the universities, and the teachers' willingness to try out various student-centered learning methods. Considering the fact that, learning outcomes were explicitly defined for HEIs, as well as, the quality assurance for learning and teaching standards highlighted the significance of promoting student-centeredness in HEIs, fully integration of all those elements is not an easy task for the universities (ESG,2015; Attard, Di Ioio, Geven, \& Santa, 2010). Reflecting on this point, the data gained through the quantitative research in Georgia depicts that there is still much more to be done in order to encourage creating a student-centered environment. Those hindering factors that were identified through this research are related to the need of making modifications concerning institutional level approaches. As mentioned by the majority of participants, the lack of resources for SCL, the absence of guidelines for the SCL approach at their universities, as well as, the students' negative attitude toward SCL are the main barriers that impede the process of its full integration. Suggested helpful framework (Kivistö \& Pekkola,2017) for mapping a number of aspects of institutional quality assurance, in order to embed studentcentered methods can be implemented in the case of Georgia. While talking about the level of student-centered practices integration, it is seen that practically none of the techniques are regularly applied by more than half of the research participants from three different universities. Accordingly, the student-centered practices are applied to some extent, but it is not still the main priority for the higher education institutions in Georgia. The study has several limitations, which should be mentioned:

The research was carried out within a small number of participants, which might not be representative of all teachers in Georgia. Therefore, the population of this research was restricted to the sample of the participants and the given number of teachers may not give a full picture of the problem. Another limitation is the number of higher education institutions in Georgia. The study focused on only three higher education institutions and for this reason, the findings drawn from this research are hard to generalize to the whole country. For further research, it would be nice to involve more teachers, in order to identify their perception of student-centered learning and the implementation of the methods and strategies in their classrooms. Engaging more universities will also allow seeing a more generalizable picture in terms of the degree of student-centeredness among HEIs. 


\section{Conclusion}

The results obtained in this study reveal that the challenges still exist concerning incorporating all characteristics and elements of the studentcentered learning approach in Higher Education Institutions in Georgia. Quality education is the primary concern among higher education institutions, as they all strive to improve and maintain quality to meet contemporary requirements and standards. Despite the modifications after joining the Bologna system in 2005, which has greatly contributed to making learning outcomes more explicit for higher education programs, the universities are still concerned with fostering student-centeredness. Based on the gained data, it could be seen that less than $40 \%$ of lecturers from three different universities fully integrate student-centered learning methods, which makes us state that there is also the necessity of teacher training on the issue of application of SCL techniques. This research found out some hindering factors, and surprisingly some of them are tightly related to the teachers' competence in using SCL methods. $35.00 \%$ of the participants believe that they cannot cover the syllabus, while $30.00 \%$ consider that they cannot apply it in large classes, or student evaluation is not possible with SCL techniques (27.50\%). The teachers' attitude needs to be changed by giving them more guidelines and training. Consequently, there is the need of promoting student-centered learning practices more in the classroom. It is vital to stimulate paradigm shift since it is considered to play a significant role in enhancing quality. We all have to think that we must redesign our teaching practice because the brains of students we have in our classes today may be developing significantly different ways than the brains of students we had years ago. It is essential to organize teaching and learning environments in a way to give the learners a chance to meet learning outcomes by the end of each course. The implementation of student-centered learning comprises introducing a set of pedagogical strategies and methods, which can ensure that the learning process is designed in a way to enable students to be active participants, decision-makers, and autonomous learners. Stimulating such an educational climate leads to a better quality that makes the students be ready for future challenges and meet the market demands (Harris, Spina, Ehrich, \& Smeed, 2013). Consequently, there is still a lack of explicit encouragement within higher education institutions regarding the enhancement of studentcenteredness. Hence, the gap between the full practical application of the student-centered learning methods and the perception of the concept is still a major issue that should be dealt with. Accordingly, to ensure a studentcentered learning environment, it is suggested (Gover \& Loukkola, 2018) to embed student-centered learning into university strategy, increase students' involvement in decision-making, promote active learning, offer pedagogical training, create opportunities for giving and receiving feedback. 


\section{References:}

1. Attard, A., Di Ioio, E., Geven, K., \& Santa, R. (2010). Studentcentered learning: An insight into theory and practice, European Commission, 1-46. Retrieved from https://www.esu-online.org/wp-content/uploads/2016/07/2010T4SCL-Stakeholders-Forum-Leuven-An-Insight-Into-Theory-AndPractice.pdf

2. Crozier, F., Loukkola, T. and Michalk, B. (2016). 'Revision of the ESG: finding a common view on the future of quality assurance in higher education', Journal of the European Higher Education Area, 1, p. 116.

3. Eyisi, D. (2016). The usefulness of qualitative and quantitative approaches and methods in researching problem-solving ability in science education curriculum. Journal of Education and Practice, 7(15), 91-100.

4. EUA (2018). Learning and Teaching in Europe's Universities: An EUA position paper (Brussels, EUA). Retrieved from

5. https://eua.eu/resources/publications/340:learning-and-teaching-ineurope\%E2\%80\%99s-universities-an-eua-position-paper.html

6. Fadel, C., Trilling, B., \& Bialik, M. (2015). Four-dimensional education: The competencies learners need to succeed. Center for curriculum redesign.

7. Gaebel, M. and Zhang, T. ( 2018). Learning and teaching in the European Higher Education Area (Brussels, EUA). Retrieved from http://bit.ly/EUATRENDS2018

8. Gover, A. and Loukkola, T. (2018). Enhancing quality: From policy to practice (Enhancing Quality through Innovative Policy \& Practice/EQUIP). Retrieved from http://bit.ly/30mvwM2

9. Gover, A., Loukkola, T., \& Peterbauer, H. (2019). Student-centered learning: approaches to quality assurance. EUA (European University Association).

Retrieved from https://eua.eu/resources/publications/884:the-qualityassurance-of-student-centred-learning-approaches-to-qualityassurance.html

10. Harris, J, Spina, N, Ehrich, L \& Smeed, J. (2013). Literature review: Student-centred schools make the difference, Australian Institute for Teaching and School Leadership, Melbourne. Prepared in partnership with the Queensland University of Technology.

11. Kaput, K. (2018). Evidence for student-centered learning. Education Evolving, 1-28.

Retrieved from https://files.eric.ed.gov/fulltext/ED581111.pdf 
12. Kivistö, J. and Pekkola, E. (2017). Quality of Administration in Higher Education (Sveriges universitets- ochhögskoleförbund (SUHF). Retrieved from

13. https://www.researchgate.net/publication/319164758_Quality_of_Ad ministration_in_Higher_Education

14. Sallis, E. (2002). Total Quality Management in Education (3rd ed.). London: Kogan Page.

15. Standards and Guidelines for Quality Assurance in the European Higher Education Area (ESG). (2015). Brussels, Belgium.

16. Shofer, S. L. (2020). Student-centered learning and pedagogical choice in the American college classroom: Perspectives from international teaching assistants. Dissertation, University of North Carolin, Chapel Hill. Retrieved from https://cdr.lib.unc.edu/concern/dissertations/sx61ds30z

17. Suresh, P., \& Rajest, S. S. (2019). An analysis of psychological aspects in student-centered learning activities and different methods. Journal of International Pharmaceutical Research, 46(1), 165-172.

18. Tvaltchrelidze, N., \& Aleksidze, N. (2019). Exploring the studentcentered classroom management and self-actualization tendencies in Georgian classrooms. Journal of Education in Black Sea Region. 4(3), 160-171.

19. UNICEF. (2000). Defining Quality in Education. New York: UNICEF.

20. Union, T. E. (2015). Bologna with Student Eyes 2015:Time to meet the expectations from 1999. Brussels: European Students' Union-ESU.

21. Vavrus, F, Thomas, M \& Bartlett (2011). Ensuring Quality by attending to inquiry:

22. learner-centered pedagogy in sub-Saharan Africa, International Institute for

23. Capacity Building in Africa, UNESCO, Addis Ababa. Retrieved from http://unesdoc.unesco.org/images/0021/002160/216063e.pdf

24. Warming, R. and Frydensberg, P. (2017) Principal in Own Learning Student-centered Learning Viewed Through the Eyes of an External Quality Assurance Agency. EQAF Paper. Retrieved from http://bit.ly/2LJ6XFl

25. Zohrabi, M., Torabi, M.A., Baybourdiani, P. (2012). Teacher-centered and/or Student-centered Learning: English Language in Iran. English Language and Literature Studies 2(3,) Cited in Emaliana, I. (2017). Teacher-centered or student-centered learning approach to promote learning?. Jurnal Sosial Humaniora (JSH), 10(2), 59-70. 